\title{
TRUE CRIME WRITINGS IN COLONIAL INDIA
}

The emergent culture of crime writings in late nineteenth-century colonial Bengal (India) is an interesting testimony to how literature is shaped by various material forces including the market. This book deals with true crime writings of the late 1800 s published by 'lowbrow publishing houses'-infamous for publishing 'sensational' and the 'vulgar' literature-that had an avid bhadralok (genteel) readership.

The volume contains the author's translations of selected true crime writings by Bakaullah and Priyanath Mukhopadhyay who worked as darogas (Detective Inspectors) in the police department in mid- to late nineteenth-century colonised Bengal. These published accounts of cases (in Bangla) investigated by them are among the very first manifestations of the crime genre in India. The writings reflect their understandings of criminality and guilt, as well as negotiations with colonial law and policing. Further, through a selection of cases in which women make an appearance either as victims or offenders (or sometimes as both), this book sheds light on the hidden gendered experiences of the time, often missing in mainstream Bangla literature.

Combining a love for suspense with critical readings of a cultural phenomenon, this book will be of much interest to scholars and researchers of comparative literature, translation studies, gender studies, literary theory, cultural studies, modern history, and lovers of crime fiction from all disciplines.

Shampa Roy is Associate Professor at the Department of English, Miranda House, University of Delhi, India. Her recent publications include Gender and Criminality in Bangla Crime Narratives in Late Nineteenth and Early Twentieth Centuries (2017), In Zenanas and Beyond: Representations of Indian Women in British Colonial Texts, 1800-1935 (2011), and "Bad" Women of Bombay Films: Studies in Desire and Anxiety (2019, co-edited with Saswati Sengupta and Sharmila Purkayastha). Dr Roy's articles on topics ranging from Victorian memsahibs' writings to postcolonial pedagogy have appeared in international journals like Feminist Review, Interventions, and Studies in Travel Writing. Her areas of research interest include the nineteenth-century and early twentieth-century English novel, popular literature, and crime fiction (in English and translations into English as well as Bangla). 


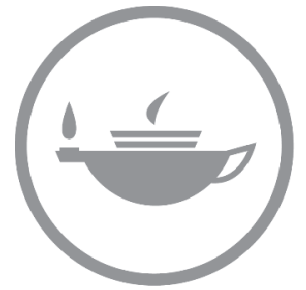

Taylor \& Francis
Taylor \& Francis Group http://taylorandfrancis.com 


\section{TRUE CRIME WRITINGS \\ IN COLONIAL INDIA}

Offending Bodies and Darogas in Nineteenth-Century Bengal

Shampa Roy

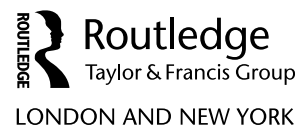


First published 2021

by Routledge

2 Park Square, Milton Park, Abingdon, Oxon OX14 4RN

and by Routledge

52 Vanderbilt Avenue, New York, NY 10017

Routledge is an imprint of the Taylor \& Francis Group, an informa business

(C) 2021 Shampa Roy

The right of Shampa Roy to be identified as author of this work has been asserted by her in accordance with sections 77 and 78 of the

Copyright, Designs and Patents Act 1988.

All rights reserved. No part of this book may be reprinted or reproduced or utilised in any form or by any electronic, mechanical, or other means, now known or hereafter invented, including photocopying and recording, or in any information storage or retrieval system, without permission in writing from the publishers.

Trademark notice: Product or corporate names may be trademarks or registered trademarks, and are used only for identification and explanation without intent to infringe.

British Library Cataloguing-in-Publication Data A catalogue record for this book is available from the British Library

Library of Congress Cataloging-in-Publication Data

A catalog record has been requested for this book

ISBN: 978-0-8153-6050-6 (hbk)

ISBN: 978-1-003-08762-5 (ebk)

Typeset in Sabon

by MPS Limited, Dehradun 
For all those readers who like to have their spines chilled and their blood curdled by a good mystery! 


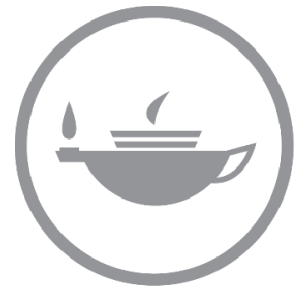

Taylor \& Francis
Taylor \& Francis Group http://taylorandfrancis.com 


\section{CONTENTS}

A note on spelling and transliteration

ix

Acknowledgements

1 Introduction 1

2 Bakaullah's preface 16

3 'Handless Harish': 'horrible homicide, three murders'

4 'A can of worms': 'a wily woman and the terrible wages of sin'

5 'Ray Mahashay': 'a great conspiracy and warring factions'

6 'What's this! A murder?': '(the sensational mystery of a man caught with his stabbed wife)'

7 'The aerial corpse': '(a shocking and sensational incident!)'

8 'A severed head': '(the search for unclaimed property)' $\quad 87$

9 'Girijasundari': '(a woman killed on the capital's thoroughfare)' 
10 'Promoda': '(havoc wreaked by a wife's illicit liaison)'

11 'Why! What's this?!': '(suicide or homicide)'

12 'Imprudence': '(the terrible misjudgments of a foolish woman)' 


\section{A NOTE ON SPELLING AND TRANSLITERATION}

Here are some of the rules that I have followed while transliterating Bengali terms into English.

All non-English terms, except proper nouns and names of people, are italicized wherever they appear in the text, without exception. Hence, thhana, chaukidar, babu and so on. Caste and community names have not been italicized, but they have been capitalized; for example, Dom, Sadgop, Brahmin, Bagdi and so on.

Words like Boishnobi have been transliterated keeping in mind the Bengali pronunciation even though many readers might be familiar with the word being Romanized as Vaishnavi.

Names of places-cities, towns, villages and districts-have been transcribed using the more popular or recognizable spellings of these places in English. Certain key places that appear in the book and have numerous pronunciations and spellings both in scholarly writing as well as administrative documents are spelled across the book like this: Medinipur/ Midnapore as Medinipur, Navadvipa/Nabadvipa/Nabadwip/Naboddip as Nabadwip and Kolkata/Calcutta/Kolikata as Kolkata. 


\section{ACKNOWLEDGEMENTS}

The greatest debt that I owe is to the darogas whose case accounts opened my eyes to the possibilities of crime writings in the late nineteenth century beyond the ubiquitous Holmesian model. Their meticulously recorded accounts of criminal investigation in Bangla take their readers on journeys that are very different from the ones envisioned by Doyle's fictions. Unlike Doyle's hero who sets out to dazzle with his ratiocinative powers, the daroga narrators give us investigative processes that are protracted and often riddled with errors of judgement and missteps that make the investigator hero far more fallible and realistic. As such, the experience of reading these contemporaries of Holmes, who had actually worked as detectives in the police department in colonial Bengal, was a novel one that pushed me to translate these writings for a wider audience.

A huge thanks to Routledge and to Aakash Chakrabarty in particular for expressing interest in this translation project, extending every possible support to facilitate the journey and answering all queries with a great deal of patience and understanding. Without Aakash, Brinda, Sophie and Cathy this book would not have seen the light of day.

As Visiting Research Fellow in the School of Law, Politics and Sociology (27 May to 7 June, 2019) at the University of Sussex, I was able to focus on my work without any worries. I am extremely grateful to Prof. Elizabeth Seal for all her help and for making me feel at home on the bewilderingly large campus. I'll always treasure my memories of discussing the fascinatingly diverse area of crime studies with her.

Being chosen for The Charles Wallace India Trust (CWIT) Visiting Fellowship 2019-2020 allowed me to work at the British Centre for Literary Translation (BCLT) in the University of East Anglia, UK for nearly two and half months, and helped my research and the final putting together of the manuscript in immensely fruitful ways. I am extremely grateful to Dr. Bijaylakshmi Nanda for granting me leave from college so I could visit UEA and focus on completing my book. To Anna Goode I'll always be thankful for all her help and encouragement while I was working at UEA. I learnt a great deal about the histories, theories and politics of translation from 
Prof. Duncan Large, the Director of BCLT. Both Duncan and Anna made sure I was able to work in an amenable environment at the UEA campus. The seminars related to Translation Studies as well as Crime Fiction at UEA were enriching in terms of yielding both scholarly insights as well as valuable friendships. The papers that I presented at the University of Sussex and at UEA were based on early drafts of my book and the warm response that they received assured me that macabre mysteries always find an interested audience. A huge thank you to Stuart and his family for making my stay in Norwich so wonderfully comfortable.

My friends and colleagues, Saswati Sengupta and Sharmila Purkayastha, implicitly understand and support the importance of research-based work, especially on 'bad' women. Even while working on separate projects, we always have enough to share, argue and laugh about. My sister Sangeeta is the other crime genre aficionado in the family and my reading of an interesting crime novel is never complete without animated discussions with her. As always, Rajarshi was dragged willy-nilly into sharing this journey of birthing a book with all its woes and joys, excitement and worries. Without his unstinting help, the book would not have been possible. 


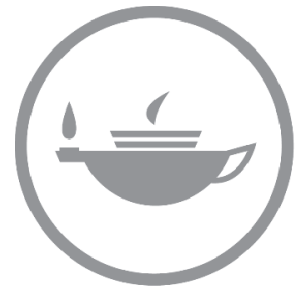

Taylor \& Francis
Taylor \& Francis Group http://taylorandfrancis.com 


\section{1 \\ INTRODUCTION}

Writings centred on crime and detection emerged in the 1890s in Bangla, when darogas (Detective Inspectors in the colonial Police Dept. in Bengal) began to write and publish what were supposed to be true accounts of cases that they had investigated. Accounts of investigation by darogas like Bakaullah and Priyanath Mukhopadhyay are, for all intents and purposes, the earliest manifestations of a dedicated crime genre in Bangla. They are the earliest cultural consequences of the newly introduced legal processes and protocols of investigation which werealso of popular interest in imported European crime fictions in colonial Bengal. Such is the iconic stature of Saradindu Bandopadhyay's Byomkesh Bakshi (who made his appearance on the horizon of Bangla crime writing in the 1930s), fuelled by the spectacular renaissance the fictional detective has enjoyed in recent cinema and tv, that it has led to an unfortunate eclipsing of the importance of his predecessors like darogas Bakaullah and Mukhopadhyay, who pioneered the field of crime writings in Bangla. Emerging as they did in the late nineteenth century, the darogas' crimecentred writings were new forms of cultural articulation and reflected a response to transformations in the domain of criminal investigation, policing and law in Bengal under colonial rule. ${ }^{1}$ Immensely popular amongst contemporary readers of late nineteenth century Bengal, these writings deserve greater attention from modern readers, especially crime genre enthusiasts, and to be read as meticulously crafted accounts of crimes and criminal investigation of the time. They also yield rich insights into the social formation within which they were produced. This volume, with its ten translated case accounts-three of Bakaullah and seven of Priyanath Mukhopadhyay-from their original Bangla, hopes to make these non-canonical writings available to a wider spectrum of readers who are unable to read them in their original language (Dasgupta and Pal, 2013; Mukhopadhyay, 2004).

II

Crime-centred writings can often yield rich insights into the social experience of the historical moment in which they were produced. The 
fascinating enterprise of pursuing clues and leads and investigating mysteries also inevitably lead to engagements with questions about why and how crime and criminality were understood, defined and dealt with in their contemporary contexts. And since questions related to criminality cannot be fully understood without delving into several social and ideological issues that cluster around the ever-changing boundaries between legitimate and illegitimate behaviour within specific social locations, the pursuit of such questions becomes an exploration of the historical moment in all its varied complexity. As such, crime-centred writings like the daroga accounts not only enhance and refine our understanding of what was constructed as crime, culpability and notions of justice and redress within their contexts, they also provide a window into many aspects of life and law in the late nineteenth century period in Bengal.

The accounts selected for translation are of cases in which women make an appearance either as victims or offenders, or, more interestingly, as both. Many of the investigations described in the accounts bring to light female acts of resisting and undermining of normative gendered roles and duties. These female transgressions and assertions of agency took place within a context which is associated with the relentless debating of the so-called "woman question" as it took shape in colonial Bengal. The education of 'upper'-class/ caste women (its extent, nature and ill-effects), their attire, mobility, roles and duties within the familial space, the age of consent, their lives as widows-all these issues and more, related largely to the construction of emulation-worthy models of upper caste Hindu/Bengali/Indian femininity, generated reams of hortatory and prescriptive writings in mid-late nineteenth-century Bengal. A considerable amount of discursive labour in the field of Bangla writings at that time was expended on describing the duties and virtues of the putatively quintessential Hindu ramani (woman) and her body, "a locus of unconquered purity ... moulded from infancy by a shastric regimen” (Sarkar, 2013: 143). Epithets like sati-lakshmi and griha-lakshmi were popularly deployed to consolidate highly restrictive ideals of femininity that were linked to an inviolable and monolithic Hindu identity, as well as to the sanctity of the hindu griha (hindu household). ${ }^{2}$ These ideas were further strengthened when tied to ideas of the nation.

Colonial law was largely complicit with brahmanical patriarchy in denying women any personhood outside of roles governed by the strictest of familial and caste-bound codes. It helped reinforce patriarchal regulations and controls to curb any possibility of female expression of desires for socially unsanctioned intimacy. Young widows, for instance, could be punished with a death penalty if found guilty of attempting to abort/having aborted unwanted pregnancies. Within the caste-patriarchal system, a widowed woman's sexual life was seen as ending with the death of her husband and she was then subjected to extremely rigid codes of enforced celibacy and austerity. Fear of harsh social and familial reprisals left widows with no 
choice but to abort pregnancies that resulted from either consensual liaisons or rapes. Besides strengthening the excruciating proscriptions that bound upper-caste widows' lives and sexuality, the criminalizing of abortion made them vulnerable to potential harassment and intimidation by local authorities and police officials. ${ }^{3}$ Similarly, Sections 366 and 498 of the newly codified laws framed women exclusively as potential victims of "enticement" and "abduction" and refused to grant them any sexual agency or to view them as capable of making choices in cases of elopement. The framing of elopement as "abduction" also made it easier for families to forcibly bring back those women who had chosen to elope with their lovers. ${ }^{4}$

At the same time, colonial laws chose not to intervene in the various forms of violence that women were subjected to within the domestic space. Investigation began only when the violence turned homicidal. Most of the investigated homicides described by the daroga narrators in the translated accounts, for instance, are the consequence of wrathful men "punishing" wayward female relatives for imagined/real sexual infractions. Buried in the accounts are fascinating tales of women who, despite the severity and all-pervasive nature of controls, found the courage to act in ways that threatened the patriarchal system. These are real life stories of ordinary women who were not passive upholders of the oppressive ideals of patriarchy, but resourceful and strong individuals who desired better/different worlds of social and sexual relationships and opportunities, and were often unafraid to escape familial ties and homes in search of them. Battered, brutalized, killed, humiliated, threatened and exiled from home, the difficult daughters, wives and widows in these accounts draw our attention to hidden gendered experiences of the time that have not always found their way into mainstream literatures in colonial Bengal. ${ }^{5}$ Embedded in these popular texts and refracted through the patriarchal prejudices and paranoia that shape these writings, there are women's voices and stories which can be retrieved and read not as evidence of "culpable" behaviour, but of rebellious assertion of female agency and desire. ${ }^{6}$ Given the paucity of nineteenth-century material in Bangla that record ordinary women's voices, the reported dialogue between the daroga and potential witnesses, or women's statements/ejahar, are undeniably valuable for helping us recuperate some lost tales of resistant femininity.

\section{III}

Undeniably, as a crime-centred genre, the daroga accounts were a legatee of the colonial encounter. For one, their emergence was tied to the ways in which crime and criminality were defined and dealt with in a context shaped by the formation of modern institutions and procedures related to crime - the momentous codification of criminal law, the formation of a police dept. and the development of "scientific" techniques of investigation such as anthropometry, fingerprinting and forensic post-mortems. 
It was in 1861, following the Indian Rebellion of 1857 and the assumption of direct rule by the British Government, that the provincial police forces of British India were unified and a "modem" police organization was established. ${ }^{7}$ The 'new police' idea was formulated within a broader context of establishing British administrative, legal and civil hegemony within India, and the evolution of the police continued to support these purposes. With Act V of 1861, which still governs India's present-day provincial police forces, the Police Code was devised for the first time and the system of regular town patrol was introduced. It made a number of changes in the police organisation, and marked the increased importance of the police as an institution of colonial control in India. As Peter Robb has noted:

placing the developing police force in a broader context of imperial purposes in India, it is seen that it long remained a largely symbolic representation of power and order.

(Robb, 1991: 129)

The highest-ranking positions of Superintendent and above were monopolized by European officers, while the lower ranks of the police-the positions of Inspector, Sub-Inspector, Head Constable and Constable-were the province of Indians, although there were some European Constables, Head Constables and Inspectors, particularly in cities and ports. In 1868, a dedicated Detective Dept. was set up in Kolkata by the Commissioner of Police, Stuart Hogg, almost a decade before the emergence of the same in Scotland Yard. Special rules were framed regarding investigation and for the first time culpable homicide, burglary and grievous hurt were termed "special report cases".

The image of the daroga as constructed in the accounts of Bakaullah and Mukhopadhyay — as that of a dexterous and dogged pursuer of leads and criminals-militated against popular contemporary stereotypes of local police officers and darogas as corrupt, boorish, venal and inefficient. Trenchant criticism of the police was published with great regularity in Bangla newspapers and periodicals like Sadharani, Som Prakash, Hindu Sanskarak and Hindu Ranjika. ${ }^{8}$ In these writings, police officials, especially the darogas of villages and muffosil areas were described as insensitive, ignorant, greedy, oafish and overweening bullies. They were also represented as being complicit with wealthy landlords and only interested in lining their own pockets. Quite often, however, the critique of the police would also become a scathing expression of class snobbery mingled with religious and casteist prejudices. The deplorable state of the police department, in such writings, is ascribed to the fact that "men of low caste" and "uneducated mussalmans" enjoyed a monopoly of the offices of darogas and jamadars. Throughout the nineteenth century, the colonial administration also bemoaned its inability to attract "educated" or 
"respectable" Indians in sufficient numbers for the positions of Inspector and Sub-inspector.

The number of Bengalees have fallen from 330 in 1875 and 311 in 1876 to 274 in 1877 . The difficulty of finding Bengalees of intelligence and education who are content to enter in the lower grades and earn promotion by good service, is very great; but it is thoroughly understood that men of this stamp are essential for detective purposes and when good men can be obtained, they are readily accepted. C. T. Metcalfe, Annual Administrative Report, April 30, 1878.

(Chattopadhyay, 1982: 137)

Critics of the system however pointed out that the dropping numbers could be linked to the government's refusal to increase salaries of Indian police officers and its obstreperousness about keeping administrative expenses at the lowest level possible. ${ }^{9}$

\section{IV}

Based on Bakaullah's preface to his case accounts, in which he briefly talks of the circumstances in which he became a daroga, it is possible to conclude that he was recruited in the 1840s when the East India Company was obsessively focused on stamping out thuggee and Commissioner Sleeman was searching for courageous and intelligent young Indian men to help him in his mission. ${ }^{10}$ Not much is known about Bakaullah, except that he was born into a well-to-do family in a village in the Hooghly district of Bengal and subsequently moved to either Kolkata or some other town to complete his education in a madrassa. In his preface, Bakaullah talks proudly of the daroga's post as one that was associated with prestige, power and wealth, and describes being thrilled when the post was offered to him while he was a young student. His name surfaces in a letter dated 2nd July, 1868, written by Special Duty Inspector General of Police, J.H. Reilly, to the Personal Assistant to the Inspector General of Police, where he draws the Inspector General's attentions to Detective Inspector Munshi Bakaullah's (spelt Bakaoollah in his letter) "successful exertions" and talks of him as deserving "great credit for the zeal and intelligence he has displayed" in arresting a gang of poisoners that ran their operations between Gaya and Ranigunge (Bengal Judicial Proceedings, 1868). ${ }^{11}$

Priyanath Mukhopadhyay (1855-1917) joined the Kolkata police department in 1878 and retired in 1911 after working as a daroga for 33 years. He started publishing his case accounts in a journal called Anusandhaan (Investigation) from 1889, but soon after began serializing the accounts in a monthly magazine called Darogar Daftar. ${ }^{12}$ Darogar Daftar was devoted entirely and exclusively to Mukhopadhyay's 
eagerly-awaited narratives about crimes and their investigation anchored, for the most part, in real events, people and experiences. ${ }^{13}$ In the 1898 Baishakh/April edition of Darogar Daftar, its editor/publisher Baninath Nandi asserts about the novelty of this enterprise:

We do not include anything that has been embellished by our imagination in these books. Only real incidents have been written about ... Darogar Daftar is an absolutely new kind of a book in every possible way. This kind of writing has never before been published in the Bangla language. Even though it is often written in the narrative form, it can definitely not be called a novel full of imagined things.

(Nandi, 1898: 4)

Darogar Daftar was the longest running serialized journal largely devoted to true accounts (prokrito ghhotona) of crime-solving. It ran for nearly twelve years and described to its readers what was meant to be read as an arduous and objective investigative process-anusandhaan-which would consolidate their faith in the infallible workings of the law. The anusandhaan is described in these accounts in terms of viewing corpses with forensic acumen, interrogating suspects, gathering information, pursuing possible leads in search of evidence, deciding what might constitute relevant evidence after sifting through the collected information, analysing it and arriving at conclusions leading to the final uncovering of the "truth" about the crime.

\section{V}

There is no gainsaying that, generated by colonial forms of policing, the daroga writings also owed their existence to a context shaped by the multiple and complex cultural consequences of colonial education, the burgeoning of print culture and the formation of an avid middle-class readership. They debuted in a colonial Bengal in which the print industry had expanded exponentially over the nineteenth century thanks to fast-growing indigenous presses clustered largely in what was the battala area of North Kolkata. ${ }^{14}$

Furthermore, it was a context where Vidocq's memoirs, Eugene Sue's Mysteries of Paris, Reynolds' Mysteries of London, the novels of Wilkie Collins and Mary Braddon and the adventures of fictional detectives like Sexton Blake and Sherlock Holmes were all extremely popular amongst Bengali readers. ${ }^{15}$ Some read them in English, others when they were translated or adapted into Bangla. ${ }^{16}$ Annual reports of libraries, like the Kolkata Public Library in the late nineteenth century, suggest that fiction (both English and Bangla) circulated the most and that writers like Doyle, Collins, Reynolds and Eugene Sue were never short of readers. Their 
overwhelming popularity, for instance, is satirically represented in Tagore's short story called Detective through the protagonist, a police detective and a crime genre afficionado whose passion for the genre is indistinguishable from anglophilia. Such unquestioning enchantment with the English language and literatures and wistful admiration for the unfamiliar urban landscapes of Paris and London are mocked and shown as resulting in a skewed perspective on reality and self-destructively delusional behaviour (Tagore, 1899/2001: 307-312).

Anglophilia of this kind was also clearly evident amongst some of the Bangla writers of crime fiction who privileged the Eurocentric vision and appeased their readers by producing "chhayabalambans" (De, 1905: 1) of European crime writings. ${ }^{17}$ This was especially the case when, in the wake of the phenomenal popularity of Conan Doyle's fictions, many Bangla writers of crime fiction turned invariably to the Holmesian model for inspiration. But equally there were readers, writers and publishers of Bangla crime who critiqued and eschewed indigenous writings that attempted little other than obvious and crude regurgitation of their western sources. As one reader of Bangla crime writing asserts, the need of the hour was not "incompetent translations of English or French crime writings", but texts written in ways "entirely the writers' own" (Bangabashi, 1906, in Ghosh, 2011: 7). The daroga writings, especially Mukhopadhyay's Darogar Daftar series, which were contemporaneous to the Holmes fictions, garnered immense popularity amongst Bangla readers of the time without being mimicries or reproductions of western models. Readers of the daroga series were also repeatedly reassured by Baninath Nandi that they were authentic records of crime-solving by an actual police detective and nothing like the salacious kechhas or sensational descriptions of scandalous liaisons associated with the battala presses. ${ }^{18}$ Plied with assurances that the series would "specially make every effort ... to enhance and strengthen the Bangla language", readers of Mukhopadhyay's accounts grew in numbers and by the seventh year of its publication, Nandi could proclaim with justifiable pride:

Today Darogar Daftar has entered its seventh year. In this country rarely does a journal retain its popularity in a consistent manner for so long. Undoubtedly this is a matter of great pride. The life and success of such journals depends entirely on their readers. It is because we have such kind readers that we are able to feel proud today. ${ }^{19}$

(Nandi, 1898: 3)

In Mukhopadhyay's own words, Darogar Daftar were based on "Those various cases that (I had) solved or at times, failed to solve, during the long period spent working as a police officer" (Dasgupta, 1958: 4). Inhabiting a 
space that overlaps with some of the recognized categories of crime writing in which "detection" of crime is the pre-eminent generic trope-police procedural, detective, true crime, mystery, police memoir-the accounts are difficult to tie down in terms of any prescribed typologies and remain separate and distinctive in their representation of the investigative process. As Nandi goes on to say,

Darogar Daftar is a completely new kind of book. Never before this has anything like it been published. Which is why many readers haven't yet been able to decide what category of writing it fits into and whether to call it fiction or poetry. But even though its written in the form of a narrative, it cannot be called a novel full of imagined events. Nor can its writer be called a novelist.

(Nandi, 1898: 4)

Shaped by colonial policing and legal systems, the daroga writings that mediate "prokrito ghotona"-real events-of investigation and bring to light many buried tales and voices, also ended up as supplements to "the institutionalised stories told in courts and police stations" as well as "the culturally authoritative texts of the law" (Rowland, 2001: 17). Furthermore, unlike in most conventional English crime fictions of the time where the "solving" of the case by the triumphant detective becomes synonymous with a reassuring, social order-affirming denouement, the daroga narratives often offer less-than-reassuring closures. They don't end with the detective's triumphant identification of the criminal but afford glimpses of what happens in the trials that follow. And in doing so, they often leave readers with a sense of unease and uncertainty about the inequities and contradictions in the judicial system.

As such, these writings are testament to the mutable and fluid nature of the crime genre and to the need to look beyond generic conventions and formulae tied to the Anglo-American "grand tradition". ${ }^{20}$ Their meandering plots and uncertain endings draw our attention to discrete evolutions of the genre in different historical contexts and push for the importance of reading them in terms of the social/political context in which they have been produced. ${ }^{21}$ Thus despite being contemporaries of Holmes, for instance, the two darogas do not describe their investigations as spectacular feats of casesolving achieved through dazzlingly individualistic acts of ratiocination and clue-reading. Their writings display long-drawn, meticulously-undertaken investigations that often involve misreading of evidence as well as tedious pursuit of leads and of obstreperous, tight-lipped witnesses who refuse to trust the police. ${ }^{22}$ In the accounts of both darogas, frustrating failures and bitter disappointments are often what characterize the investigative process. Their hardships are also compounded by the fact that, unlike Holmes who can simply dismiss the authority of doltish police officials like Lestrade, the 
darogas are only too aware of being colonized subjects and chakurijibis (employees) bound by the requirements that their positions impose on them. Their fraught relationship with colonial authority is laid bare when they refer bitterly to themselves as beleaguered employees of the colonial govt., duty-bound to fulfil every arbitrary order and every oppressive demand of their superior officers.

While the local police has been asked to assist in every possible way, the primary responsibility of looking into this case has been assigned to me. Given that in this job we have to keep a record of even the number of times we go out to urinate, do I have a choice but to follow orders?

(Bakaullah, Ray Mahashay, 1890 (approx.)/2013: 65)

It is so very easy for a superior officer, to issue orders of this kind to his junior officer. But what never ceases to surprise me is why our superiors are unable to give us any suggestions as to how such orders are to be followed. At any rate, once I get my orders, I have no choice but to follow them, to the best of my abilities whether I succeed or fail in my mission.

(Mukhopadhyay, E Ki Khoon, Vol. 1, 1894/2004: 156)

We are a colonized race. We have no choice but to obey orders. (Mukhopadhyay, Girijashundori, Vol. 1, 1895/2004: 220)

When daroga Mukhopadhyay narrates his negotiations of colonial authority, what becomes clear is that he wants his readers to view him sympathetically not only as a disenfranchised colonized struggling to fulfil the demands of his profession, but also as one whose anxieties and dilemmas stem equally from his deep investment in the normative hierarchies and social codes related to caste/class/gender associated with conservative constructions of a Hindu bhadralok identity. The references to his anxious struggles to uphold such beliefs and ideals at any cost, even when they become incompatible with his professional commitments, help consolidate his credentials as a diligent professional, a put-upon colonized subject and most importantly, a Hindu bhadralok acutely aware of his caste/class status. ${ }^{23}$

Hindus of this country never (especially in the evenings) touch a corpse or even objects related to the corpse. But despite being Hindus, we police officers are never able to observe such rules. Despite knowing that I would have to take a bath later that night after touching the things of a dead person, I fulfilled the demands of my duty.

(Mukhopadhyay, Balihari Buddhi, Vol. 1, 1894/2004: 193) 
Predicaments arising out of such simultaneous commitments become especially evident in accounts of cases where women across caste and class surface as witnesses, perpetrators or victims of crimes that disrupt patriarchal ideals of social coherence. And interestingly, while patriarchal censure shapes both darogas' responses to female transgressors, their tacit complicity in caste/class hierarchies is evident in their extreme caution when investigating possible infractions by upper caste/class women and their concern about the potential social disgrace and ruined reputations of affluent households that come under the scanner during the investigation. In Ray Mahashay, daroga Bakaullah talks of his anxieties while traveling to investigate the alleged abortion by a powerful zamindar's sister.

The case involved a high-born young woman of an affluent family; she was a zamindar's sister and she lived in the inner quarters of the household. How was I going to investigate her? How was I going to go around collecting facts about the case? I became frantic with worry as I wondered about these things.

(Bakaullah, Ray Mahashay, 66)

His subsequent musings about the case suggest that he sees himself as working within a social system where inequalities of wealth and privilege often decide the nature and extent of the investigative process. Daroga Mukhopadhyay, in fact, freely admits to undermining and subverting the law, in order to preserve the reputation of upper caste/class women and their families in his accounts of cases titled Aashmani Laash (Aerial Corpse) and Kubudhhi (Imprudence). In contrast, when interrogating women who either belong to poor families or survive in the metropolis by working as domestics, he has no qualms about resorting to high-handedness and intimidation or even representing their victimhood as well-deserved comeuppance for their sinful acts.

\section{VI}

The translating of these records poses several challenges, many of which have to do with the fact that the word order in Bangla is often quite different from that of English. As such, despite Venuti's assertions about the dangers of "domesticating" the source text by minimizing its foreignness in the target text, and Spivak's critique of "translatease", the absurdity of a literal translation has been avoided (Venuti, 1998: 241, Spivak, 2012: 314-16). Bangla seems to be a more dense language, and often retaining the integrity of the original means having to break up the lines in English. In Bangla, many prepositional relations are created by inflecting nouns, definite articles are simply understood and plural or singular nouns are perceived from the context. Also, at times certain words are 
so saturated with cultural meanings that the pedantry of footnoting becomes unavoidable. Despite such problems and conundrums, my translation has remained as faithful as possible to the darogas' painstaking record of the tortuous process of investigation, so different from narratives devoted to displaying the virtuoso performances of fictional detectives likes Holmes. The fastidiously described minutiae of the investigative process also throws up the multiple and conflicting perspectives and voices that intersect with the omniscient narrative and help produce a heteroglossia of responses to gendered questions of guilt and justice. For it is these that make it relevant within our context, which continues to be haunted by some of these questions.

Note: The exact publication dates of Bakaullah's writings not being known, they could not be mentioned along with the case accounts. However, since Bakaullah joined the police in the 1840s, almost three decades before Priyanath Mukhopadhyay, his cases have been placed before those of Mukhopadhyay.

\section{Notes}

1 Girish Chandra Basu's Sheykaaler Daroga $r$ Kahini (The Tales of a Daroga Those Days) published in 1885 is also a daroga account of the time. Basu's account is mostly focused on his experiences and adventures as a thug/ dacoit chaser.

2 Both words gesture at the ideal wife of Hindu brahmanical patriarchy. "Sati recalls the goddess as the sacrificing wife whose myths ideologically sanctioned the horrific practice of widow immolation in parts of India while Lakshmi is the golden deity of happy conjugality" (Roy and Sengupta, 2019: 46).

3 In the account titled Ray Mahashay, it is Bakaullah's investigation that saves the zamindar's sister Saudamini from punishment and disgrace. But it is clear that the silencing of her voice and sexual agency by colonial law makes Saudamini's body an even more vulnerable site for the playing out of male conflicts and battles for power. However, in the account titled Can of Worms, Bakaullah has no sympathy for the young upper caste widow Premada who had eloped with her lover Haridas, and even plans to arrest Haridas' poor aunt for helping Premada abort her foetus.

4 The most commonly applied section with regard to abduction was Section 366, which runs thus:whoever kidnaps or abducts any woman with the intent that she may be compelled to marry any person against her will, or in order that she may be forced or seduced to illicit intercourse, or knowing it to be likely that she will be forced or seduced to illicit intercourse, shall be punished with imprisonment of either description for a term which may extend to ten years and shall be liable to fines (IPC, 1860).

5 The Amritabazar Patrika on 20 February, 1868 talked of conducting interviews with prostitutes, of whom eight admitted they had engaged in adultery, got caught and had to leave home to escape punishment or had eloped with their lovers to escape the trials of widowhood and had been subsequently deserted (Basu, 2003: 602-604). In 1872-3, Bankim Chatterjee, Deputy Magistrate of Murshidabad, along with other magistrates, was asked to write reports on the 
causes of prostitution. The novelist wrote that since "Hindu society tolerated no compromises and shut its door forever against those who broke through these restraints even once", women had no other means of survival (Chatterjee, Judicial File, Oct. 1872).

6 I am fully aware of the fact that the female "voices" heard in these writings cannot be read as being unproblematically authentic. But awareness of their being mediated does not have to lead necessarily to an invariable dismissal or repudiation of these writings as offering nothing but distorted and manipulated versions of women that only served the prevalent structures of power. As Carlo Ginzburg says in his renowned work on early modern witch trials, "The voices of the accused reach us strangled, altered, distorted; in many cases, they haven't reached us at all. Hence-for anyone unresigned to writing history for the nth time from the standpoint of the victors-the importance of the anomalies, the cracks that occasionally (albeit very rarely) appear in the documentation, undermining its coherence" (Ginzburg, 1990: 10).

7 In 1793, Governor General Cornwallis had transferred police powers from local landlords to magistrates appointed by the East India Company. Although the intention was to establish a network of thhanas or police stations presided by the daroga or police inspector, as representatives of Company power, the reality remained far more complex. For although the zamindars were stripped of their authority over local law and order, they were still relied upon to provide names for appointments to police and they also retained control over the village watch (chaukidar), as well as the power to punish their tenants through their own private lathiyals (retainers trained in wielding clouts and truncheons).

8 In his long critique of the prevalent police system in Bengal, Pulish o Lokrakhha, Ramakkhoy Chattopadhyay writes about the police in Bengal, "Arrogance, corruption and nasty behaviour seem to be requirements of their rank. They thrive on harassing people. Neither bhadralok nor abhadralok can hope to preserve their self-respect when they approach the police. When the police arrive in villages for inspection, the bhadralok of that area go into hiding. Magistrates of many districts have complained about the police officers not getting the support of local villagers during inspection tours, but none of these Magistrates have tried to get to the bottom of this matter to find out the real reasons for this" (Chattopadhyay, 1892: 35).

9 As early as in 1798 a Circuit Judge had stated that "the salary annexed to the situation (of the daroga) which hardly exceeds the wages of a respectable menial servant, is so very inadequate to the nature and responsibility of the trust, and so very inconsiderable that it deterred men of rank and character from accepting the office". Analysing the flaws of the system, Frederick Shore linked the miserable pay of the darogas to their vulnerability to corruption and said, "Sense of duty etc are all very fine words but the feelings of human nature will have their sway; if good service be wanted, the proper price must be paid for it. For it will not be obtained without" (Chattopadhyay, 2000: 67).

10 The assumption that Bakaullah was recruited at some point in the $1840 \mathrm{~s}$ is based on the fact that William Sleeman-under whom he talks of having been appointed-became Commissioner for the Suppression of Thuggee and Dacoity in 1839.

11 The exact date of the publication of Bakaullah's accounts is not known. According to Sukumar Sen they were published before 1896, but he fails to give a specific date (Dasgupta and Pal, 2013: 12).

12 The words of scholar and librarian at Bengal Library Haraprasad Shastri (who wrote brief summaries of the Bangla texts collected in the erstwhile Bengal Library) introducing the writings of Priyanath Mukhopadhyay can be found in 
the 1892 Bengal Library Catalogues (India Office Collections): "The most noticeable feature of the literature of the year in fiction is the appearance of a large number of detective stories in Bengali, entitled Darogar Daftar, by Babu Priyanath Mukharji, an officer of the Detective Department of the Kolkata Police. The stories are clever and smart ... They show the usefulness of native talent in detecting crimes in native society." Haraprasad Shastri, Catalogue of Bengali Printed Books (London: J.F. Blumhardt, 1892). Subsequently in 1894 he writes: "Babu Priyanath Mukharji continues to write his experiences as a detective officer, and has published nearly a dozen short stories during the course of the year. His stories, which appear in monthly parts, are exceedingly popular" (Ibid., 1894).

13 To ensure that his readers were not misled about the truth status of the accounts, Mukhopadhyay says that while his first person narratives are meant to be read as documenting "prokrito ghhotonaa" (actual incidents/cases) investigated by him, accounts not written in the first person were meant to be seen as fictions (Mukhopadhyay, Vol. 1., 2004: 6).

14 The field of popular writings in the late nineteenth century, though inseparable from the phenomenon of the battala, was also a contradiction-riddled and complex field because of what the battala often came to signify for bhadralok readers. Battala, which began by simply being a geographical space, gradually also accreted other meanings and came to be seen in terms of cheap, even insalubrious texts that the bhadralok was not entirely comfortable being associated with. "Battala which lasted for almost a hundred years had to fight the so-called custodians of 'high' culture continually for its survival. Many such people used to think of battala as 'bad' stuff. They would not even allow what they judged as unclean, obscene, low, trivial and unreadable battala books to enter their houses" (trans. mine) (Biswas and Acharya, 2013: 6).

15 In the decades following the onset of formal English education, an increasing number of English publications (histories, grammars, schoolbooks, poetry, novels, biographies) became available in the Indian market. Between 1850 and 1863-4, the export of books and printed matter from Britain to India doubled in value from 148, 563 pounds to 313, 772 pounds (Joshi, 1995: 39). The vast bulk of print arrived in the ports of Kolkata and Bombay.

16 Dickens' Bleak House, which, among other things, is about a crime and its investigation by a police official, was translated several times into Bangla. Wilkie Collins' novels, The Woman in White and The Moonstone were also very popular among Bengali readers and the former was translated as Shuklabasana Sundari (The Beautiful Woman in White) in the last decade of the nineteenth century.

17 The word chhayabalamban hints at a slippage between an exact reflection and an adaptation of the original.

18 While writings like Darogar Daftar (published for more than a decade from Bandhab Pustakalay and Sadharan Pustakagar presses in the Battala area) could not deny their battala association, they strove to construct their identity in terms of a vehemently insisted-upon difference from "other" more quintessential battala writings which were assumed to be "low" forms of writing in their use of non-bhadra language and vulgarity of content. Kechha (Scandal) were writings that were primarily centred on sexual scandals or homicides that had created a scandalous furore. Several Kechhas, like Mama Bhbaagini $r$ Paanchaali (The Tale of an Uncle and his Niece) and Uhb! Mama r ki Bichaar (Uhh! What shocking justice meted out by an Uncle) for instance, centred around the mama-bhhaagni liaison (incestuous relationship between a young girl and her 
maternal uncle) were printed from the battala press in the late 1870s, which were about a contemporary case involving one Upendra Basu and his niece Khhetramani Dasi. In 1884 a case of murder, this time that of a prostitute Kusum Kumari by a churlish male client Tinkari Pal who was subsequently hanged, also gave rise to a slew of kechhaas.

19 According to renowned scholar and critic of Bangla literary studies, Sukumar Sen, "Many people used to buy Darogar Daftar. In villages as well as in cities the houses of educated and bhadra Bengalis were bound to have a few copies of Darogar Daftar" (Sen, 1988: 151).

20 By the "grand tradition" of crime fiction, I am referring to the standard narratives of Anglo-American crime writing that privilege and reproduce Anglocentric perspectives and literary traditions while tracing the history of the genre. They begin with Edgar Allan Poe's The Murders in the Rue Morgue and then move through a selection of English 'classics' such as Wilkie Collins' The Moonstone (1868), followed by Holmes and Christie, and completely ignore its transnational emergence and growth.

21 Referring to the development of crime fictions in India, Stephen Knight talks of the earliest manifestations of the genre as "pulp fiction in indigenous languages relocating British models usually Sherlock Holmes” (Knight, 2015: 179). The daroga accounts however prove that not all "indigenous" crime writings were simplistic and crude derivations of the Holmesian model.

22 In the account titled Promoda, the daroga narrator draws attention to the problems faced by daroga Bansiram in getting witness accounts from the villagers. Talking of this as a problem faced by many police officers he says, "Most people in this country have very little faith in the workings of the police and as such are extremely reluctant to open up to them. What if the truth leads to their getting dragged into unnecessary police-related complications? Hence, what better adage to live by than 'the dumb has no enemies'?" (Mukhopadhyay, Promoda, Vol. 1, 1896/2004: 237).

23 In Bengal the castes are divided into two main groups: 1) Brahmin and 2) Shudra. The second group is further divided into four sub groups: a) the SatShudra (or "clean" shudras) includes such castes as the Kayastha and Nabasakh b) then came the Jalacharaniya Shudras who were those castes that were technically of the Nabasakh group from whom Brahmins and others of "high" castes could take water, like Goala, Sadgop/Gop, Kamar etc. c) the Jalabharaya Shudras from whose hands a Brahmin could not take water and d) the Asprishya Shudras whose touch is considered utterly impure and with whom all contact must be avoided like the Dom, Dhopa, Chamar, Kaivartya, Bagdi etc.

1 Girish Chandra Basu's Sheykaaler Daroga $r$ Kahini (The Tales of a Daroga Those Days) published in 1885 is also a daroga account of the time. Basu's account is mostly focused on his experiences and adventures as a thug/ dacoit chaser.

2 Both words gesture at the ideal wife of Hindu brahmanical patriarchy. "Sati recalls the goddess as the sacrificing wife whose myths ideologically sanctioned the horrific practice of widow immolation in parts of India while Lakshmi is the golden deity of happy conjugality" (Roy and Sengupta, 2019: 46).

3 In the account titled Ray Mahashay, it is Bakaullah's investigation that saves the zamindar's sister Saudamini from punishment and disgrace. But it is clear that the silencing of her voice and sexual agency by colonial law makes Saudamini's body an even more vulnerable site for the playing out of male conflicts and battles for power. However, in the account titled Can of Worms, Bakaullah has no sympathy for the young upper caste widow Premada who had eloped with 
her lover Haridas, and even plans to arrest Haridas' poor aunt for helping Premada abort her foetus.

4 The most commonly applied section with regard to abduction was Section 366, which runs thus:whoever kidnaps or abducts any woman with the intent that she may be compelled to marry any person against her will, or in order that she may be forced or seduced to illicit intercourse, or knowing it to be likely that she will be forced or seduced to illicit intercourse, shall be punished with imprisonment of either description for a term which may extend to ten years and shall be liable to fines (IPC, 1860).

5 The Amritabazar Patrika on 20 February, 1868 talked of conducting interviews with prostitutes, of whom eight admitted they had engaged in adultery, got caught and had to leave home to escape punishment or had eloped with their lovers to escape the trials of widowhood and had been subsequently deserted (Basu, 2003: 602-604). In 1872-3, Bankim Chatterjee, Deputy Magistrate of Murshidabad, along with other magistrates, was asked to write reports on the causes of prostitution. The novelist wrote that since "Hindu society tolerated no compromises and shut its door forever against those who broke through these restraints even once", women had no other means of survival (Chatterjee, Judicial File, Oct. 1872).

6 I am fully aware of the fact that the female "voices" heard in these writings cannot be read as being unproblematically authentic. But awareness of their being mediated does not have to lead necessarily to an invariable dismissal or repudiation of these writings as offering nothing but distorted and manipulated versions of women that only served the prevalent structures of power. As Carlo Ginzburg says in his renowned work on early modern witch trials, "The voices of the accused reach us strangled, altered, distorted; in many cases, they haven't reached us at all. Hence-for anyone unresigned to writing history for the nth time from the standpoint of the victors-the importance of the anomalies, the cracks that occasionally (albeit very rarely) appear in the documentation, undermining its coherence" (Ginzburg, 1990: 10).

7 In 1793, Governor General Cornwallis had transferred police powers from local landlords to magistrates appointed by the East India Company. Although the intention was to establish a network of thhanas or police stations presided by the daroga or police inspector, as representatives of Company power, the reality remained far more complex. For although the zamindars were stripped of their authority over local law and order, they were still relied upon to provide names for appointments to police and they also retained control over the village watch (chaukidar), as well as the power to punish their tenants through their own private lathiyals (retainers trained in wielding clouts and truncheons).

8 In his long critique of the prevalent police system in Bengal, Pulish o Lokrakhha, Ramakkhoy Chattopadhyay writes about the police in Bengal, "Arrogance, corruption and nasty behaviour seem to be requirements of their rank. They thrive on harassing people. Neither bhadralok nor abhadralok can hope to preserve their self-respect when they approach the police. When the police arrive in villages for inspection, the bhadralok of that area go into hiding. Magistrates of many districts have complained about the police officers not getting the support of local villagers during inspection tours, but none of these Magistrates have tried to get to the bottom of this matter to find out the real reasons for this" (Chattopadhyay, 1892: 35).

9 As early as in 1798 a Circuit Judge had stated that "the salary annexed to the situation (of the daroga) which hardly exceeds the wages of a respectable menial servant, is so very inadequate to the nature and responsibility of the trust, and so very inconsiderable that it deterred men of rank and character from accepting 
the office". Analysing the flaws of the system, Frederick Shore linked the miserable pay of the darogas to their vulnerability to corruption and said, "Sense of duty etc are all very fine words but the feelings of human nature will have their sway; if good service be wanted, the proper price must be paid for it. For it will not be obtained without" (Chattopadhyay, 2000: 67).

10 The assumption that Bakaullah was recruited at some point in the 1840 s is based on the fact that William Sleeman-under whom he talks of having been appointed-became Commissioner for the Suppression of Thuggee and Dacoity in 1839.

11 The exact date of the publication of Bakaullah's accounts is not known. According to Sukumar Sen they were published before 1896, but he fails to give a specific date (Dasgupta and Pal, 2013: 12).

12 The words of scholar and librarian at Bengal Library Haraprasad Shastri (who wrote brief summaries of the Bangla texts collected in the erstwhile Bengal Library) introducing the writings of Priyanath Mukhopadhyay can be found in the 1892 Bengal Library Catalogues (India Office Collections): "The most noticeable feature of the literature of the year in fiction is the appearance of a large number of detective stories in Bengali, entitled Darogar Daftar, by Babu Priyanath Mukharji, an officer of the Detective Department of the Kolkata Police. The stories are clever and smart ... They show the usefulness of native talent in detecting crimes in native society." Haraprasad Shastri, Catalogue of Bengali Printed Books (London: J.F. Blumhardt, 1892). Subsequently in 1894 he writes: "Babu Priyanath Mukharji continues to write his experiences as a detective officer, and has published nearly a dozen short stories during the course of the year. His stories, which appear in monthly parts, are exceedingly popular" (Ibid., 1894).

13 To ensure that his readers were not misled about the truth status of the accounts, Mukhopadhyay says that while his first person narratives are meant to be read as documenting "prokrito ghhotonaa" (actual incidents/cases) investigated by him, accounts not written in the first person were meant to be seen as fictions (Mukhopadhyay, Vol. 1., 2004: 6).

14 The field of popular writings in the late nineteenth century, though inseparable from the phenomenon of the battala, was also a contradiction-riddled and complex field because of what the battala often came to signify for bhadralok readers. Battala, which began by simply being a geographical space, gradually also accreted other meanings and came to be seen in terms of cheap, even insalubrious texts that the bhadralok was not entirely comfortable being associated with. "Battala which lasted for almost a hundred years had to fight the so-called custodians of 'high' culture continually for its survival. Many such people used to think of battala as 'bad' stuff. They would not even allow what they judged as unclean, obscene, low, trivial and unreadable battala books to enter their houses" (trans. mine) (Biswas and Acharya, 2013: 6).

15 In the decades following the onset of formal English education, an increasing number of English publications (histories, grammars, schoolbooks, poetry, novels, biographies) became available in the Indian market. Between 1850 and 1863-4, the export of books and printed matter from Britain to India doubled in value from 148, 563 pounds to 313, 772 pounds (Joshi, 1995: 39). The vast bulk of print arrived in the ports of Kolkata and Bombay.

16 Dickens' Bleak House, which, among other things, is about a crime and its investigation by a police official, was translated several times into Bangla. Wilkie Collins' novels, The Woman in White and The Moonstone were also very popular among Bengali readers and the former was translated as 
Shuklabasana Sundari (The Beautiful Woman in White) in the last decade of the nineteenth century.

17 The word chhayabalamban hints at a slippage between an exact reflection and an adaptation of the original.

18 While writings like Darogar Daftar (published for more than a decade from Bandhab Pustakalay and Sadharan Pustakagar presses in the Battala area) could not deny their battala association, they strove to construct their identity in terms of a vehemently insisted-upon difference from "other" more quintessential battala writings which were assumed to be "low" forms of writing in their use of non-bhadra language and vulgarity of content. Kechha (Scandal) were writings that were primarily centred on sexual scandals or homicides that had created a scandalous furore. Several Kechhas, like Mama Bhhaagini $r$ Paanchaali (The Tale of an Uncle and his Niece) and Uhb! Mama r ki Bichaar (Uhh! What shocking justice meted out by an Uncle) for instance, centred around the mama-bhhaagni liaison (incestuous relationship between a young girl and her maternal uncle) were printed from the battala press in the late 1870s, which were about a contemporary case involving one Upendra Basu and his niece Khhetramani Dasi. In 1884 a case of murder, this time that of a prostitute Kusum Kumari by a churlish male client Tinkari Pal who was subsequently hanged, also gave rise to a slew of kechhaas.

19 According to renowned scholar and critic of Bangla literary studies, Sukumar Sen, "Many people used to buy Darogar Daftar. In villages as well as in cities the houses of educated and bhadra Bengalis were bound to have a few copies of Darogar Daftar" (Sen, 1988: 151).

20 By the "grand tradition" of crime fiction, I am referring to the standard narratives of Anglo-American crime writing that privilege and reproduce Anglocentric perspectives and literary traditions while tracing the history of the genre. They begin with Edgar Allan Poe's The Murders in the Rue Morgue and then move through a selection of English 'classics' such as Wilkie Collins' The Moonstone (1868), followed by Holmes and Christie, and completely ignore its transnational emergence and growth.

21 Referring to the development of crime fictions in India, Stephen Knight talks of the earliest manifestations of the genre as "pulp fiction in indigenous languages relocating British models usually Sherlock Holmes” (Knight, 2015: 179). The daroga accounts however prove that not all "indigenous" crime writings were simplistic and crude derivations of the Holmesian model.

22 In the account titled Promoda, the daroga narrator draws attention to the problems faced by daroga Bansiram in getting witness accounts from the villagers. Talking of this as a problem faced by many police officers he says, "Most people in this country have very little faith in the workings of the police and as such are extremely reluctant to open up to them. What if the truth leads to their getting dragged into unnecessary police-related complications? Hence, what better adage to live by than 'the dumb has no enemies'?" (Mukhopadhyay, Promoda, Vol. 1, 1896/2004: 237).

23 In Bengal the castes are divided into two main groups: 1) Brahmin and 2) Shudra. The second group is further divided into four sub groups: a) the SatShudra (or "clean" shudras) includes such castes as the Kayastha and Nabasakh b) then came the Jalacharaniya Shudras who were those castes that were technically of the Nabasakh group from whom Brahmins and others of "high" castes could take water, like Goala, Sadgop/Gop, Kamar etc. c) the Jalabharaya Shudras from whose hands a Brahmin could not take water and d) the Asprishya 
Shudras whose touch is considered utterly impure and with whom all contact must be avoided like the Dom, Dhopa, Chamar, Kaivartya, Bagdi etc.

1 Warren Hastings (1732-1818) was Governor-General of India from 1773 to 1785. Charles Hardinge (1858-1944) was Viceroy from 1910 to 1916.

2 Bentinck (1778-1839) was Governor-General from 1828 to 1835. Thuggee Commissioner refers to Major William Sleeman, who assumed charge of the office of Commissioner for the Suppression of Thuggee and Dacoity in early 1839. During the operations that he supervised, more than 1400 Thugs were hanged or transported for life.

1 Nabadwip, along with such other provincial towns as Bishnupur, Shantipur, Katwa and Shrikhanda, were key Vaishnava sacred sites in nineteenth century Bengal that claimed a rich legacy of Chaitanya/Gauranga/Sri Gourango, the "founder" of Vaishnavism. These places were populated by gosvamis, mahants and babajis, all practitioners of sahajiya devotion (for more information on Vaishnavism see footnote 2 of Promoda).

2 Aakhra refer to places where Vaishnava mendicants or even pilgrims could stay at extremely nominal rates.

3 Srichandranath is a hill-based pilgrim spot for Hindu and Budhhist devotees (presently in Bangladesh) with a Shiva temple.

4 Refer to footnote 7 of the Introduction for thhana.

5 The word used in the Bangla original to describe the moonlight is kakjyotsna. The word is used to describe the kind of bright moonlight that gives the illusion of dawn and fools crows into cawing.

6 The dewan was the financial steward in a zamindar's/landowner's estate.

7 A naayeb was a rent collecting officer and administrator in a landlord's estate.

1 Kayastha is a caste category. Refer to footnote 23 of the Introduction for more details.

2 A caste category of a 'clean' shudra. Refer to footnote 23 of the Introduction.

3 The Bangla and Sanskrit word kula refers to a generic collectivity. The term was used more specifically in combination with the names of specific men to refer to units which would be designated as "clans", "lineages" or "families" in English. Ghosh-kula, for instance, would refer to the clan of persons who had a particular Ghosh as their "first ancestral male." Kulatyag (abandoning one's kula) was the word often used to refer to elopement. Even though it is clear that Premada and Hari had eloped together, the daroga at this point refers to the elopement

as a crime committed by Hari. He "forced Premada to abandon her kula". As discussed in footnote 4 of the Introduction, the insistence on referring to women's elopement as "being forced out of the kula" 1) helped rob women of their agency and framed their action as passive subjection and 2) helped punish the male partner for having "enticed" and "abducted" her.

4 For criminalizing of abortion see Introduction and footnote 3 of the Introduction.

5 Salaami refers to a gift of money.

1 Land gifted to a Brahmin was called brabmatra. The owners did not have to pay a tax for the gifted land.

1 I have translated the word "kalkut" as poisonous deceit. While that is one way of translating it, in Hindu Purana mythology, kalkut also refers to the deadly poison that was produced by the churning of the ocean by the deva and asura (roughly translated as gods and demons). The cultural reference embedded in the word is, unfortunately, lost in translation.

1 The inner quarters of upper caste/class households where the women of the 
family resided were out of bounds for outsiders. About antahpurs (women's quarters) in wealthy households in late 19th-century Bengal, Chitra Deb writes,

Everywhere, as far as women were concerned, there was overwhelming emphasis on aabroo (seclusion though the word also means honour), purdah (the veil), closed windows and doors. Women in their own houses, were prohibited from stepping on to the courtyards, going to terraces and there was of course never any question of their crossing the threshold on foot.

(Chitra Deb, Antahpurer Atmakatha, Kolkata: Ananda Publishers, 1984)

2 Sheendhh kaata refers to a particular kind of burglary which involves digging a tunnel in order to break into the house.

3 Chandannagar, a town in Bengal, was also known as Farashdanga since it had been a French colony. Farash is the Bengali/Bangla word for French.

4 In all probability refers to Kamini planning to trick/force her sister (Sundari) into a life of prostitution in the city.

5 Within the caste patriarchal system, a widow's sexual life was relentlessly policed by extremely rigid and austere codes of enforced celibacy, bodily mortification and food restrictions. Their marginalization and exclusion from normal familial existence and sexual life often also resulted in being sent off to social oblivion (and not infrequently, indigence) in places of pilgrimage like Varanasi/ Kashi, Vrindavan and Nabadwip. Despite the possibilities of social change opened up by the Widow Remarriage Act (1861), the formalization of usufructuary rights of widows over their husbands' property, and also the radical marriage regulation of 1872 , it was celibate widowhood that was apotheosized in the late nineteenth century context. In this case, even though the babu's daughter lived with her family, once her secret liaison becomes known to her father, she is exiled to Kashi.

1 The seventh day of the Durga Puja festivities. Panchami, shashthi, ashtami and navami are respectively the fifth, sixth, eighth and ninth days.

2 Dom refers to a so-called 'unclean' caste group found in large numbers in districts in the western fringe of Bengal. Traditionally, Doms were basket-makers, cultivators, labourers, musicians and midwives. Some were also scavengers. Refer to footnote 23 of the Introduction.

3 Sindoor refers to the vermilion mark on the forehead of Hindu women and is meant to be an identifiable mark of her being married.

1 The Kaivartyas, a scheduled caste, belonging to the regions of Assam, Bengal and Odisha, were traditionally engaged in the occupation of fishing.

2 In the epic Mahabharata, Virat was the king of Matsya and a cow baron, in whose court the Pandavas spent a year in concealment during their exile.

3 Panchayat refers to the village council or a governing body usually formed of influential old men of the village.

4 Mitin is a term of endearment for a dearly loved friend and is often used by a man for a female friend. It is clear from the account that the maid Girija gives to the daroga that both she and her employer's daughter (also Girija) think of the other as Mitin. There is also a tantalizingly vague hint at same-sex love between the two Girijas in her account which remains unexplored and attenuated.

5 Ghat refers to the banks of a river.

6 Gamchha refers to a piece of cloth used as a towel. 
1 A dao would be similar to a machete.

2 Boishnobi/Vaishnavi refers to female practitioners of Vaishnavism in Bengal which is indelibly connected to the figure of Chaitanya-a devotee, mystic and teacher who lived from 1486 to 1533 . Vaishnavism has a long and complex history both outside and in Bengal. Associated with the worship of Radha and Krishna, in Bengal it has also been significant for enabling the social mobility of non-Brahmin trading groups. In the nineteenth century it was hugely popular amongst many prominent Hindu houses as well as among so-called 'lower' classes and castes. According to Baptist missionary William Ward, at least onethird of the population of Bengal professed some form of Vaishnavism in 1815. For many Vaishnava women and men, renunciation was used as an option to leave normative caste, class, and gender roles and lead a wandering life. Boishnobi women were often literate and were even hired as teachers in elite households (like the Jorasanko Tagores) for educating the female members. From the nineteenth century, sexuality emerged (amongst certain sections of the bhadralok) as the key feature of disdain for the Vaishnavas. Terms such as "bawdy," "obscene," and "sexually explicit" were used to describe Vaishnava lyrics of the padabali kirtan. Similarly, the terms "prostitute" and "lax morals or virtues" were deployed as adjectives for Boishnobis/Vaishnavi who did not clearly belong to conservative and wealthy Vaishnava families and led unconventional lives.

1 Ghat refers to the landing-stage on the bank of a river/pond. Keoratala is a place in Kolkata where the ghat is used as a crematory.

2 Both Suvarna Banik and Goyala refer to caste groups in Bengal. While Suvarna Banik is associated with the mercantile group with dealings in gold and silver, Goyala is a caste group associated with pastoral activities. Refer to footnote 23 of the Introduction.

1 Cuttack is a town in Odisha, a neighbouring state to Bengal. Puri, another town in Odisha, is known for the famous Jagannath temple that draws several pilgrims from all over India. Oriya is a word used to refer to the inhabitants of Odisha.

2 The bagdis are a "scheduled caste" today. Variously described as "indigenous", "aboriginal" and "tribal", they are wood-cutters, fishermen, litter carriers, and agricultural wage labourers/share-croppers. Three sub-castes-Tentule, Kushmete and Mal-form this caste group. I am deeply indebted to Saswati Sengupta for the detailed information and history of caste groups in Bengal.

3 Panda refers to a network of men who operate within Puri and convince devotees visiting the Jagannath temple that they will be given a faster and smoother entry into the temple sanctum in exchange for money.

4 Often women from respectable and elite families travelled in groups (that were not necessarily segregated in terms of caste) to visit places of pilgrimage like Puri.

1 Warren Hastings (1732-1818) was Governor-General of India from 1773 to 1785. Charles Hardinge (1858-1944) was Viceroy from 1910 to 1916.

2 Bentinck (1778-1839) was Governor-General from 1828 to 1835. Thuggee Commissioner refers to Major William Sleeman, who assumed charge of the office of Commissioner for the Suppression of Thuggee and Dacoity in early 1839. During the operations that he supervised, more than 1400 Thugs were hanged or transported for life.

1 Nabadwip, along with such other provincial towns as Bishnupur, Shantipur, Katwa and Shrikhanda, were key Vaishnava sacred sites in nineteenth century Bengal that claimed a rich legacy of Chaitanya/Gauranga/Sri Gourango, the 
"founder" of Vaishnavism. These places were populated by gosvamis, mahants and babajis, all practitioners of sahajiya devotion (for more information on Vaishnavism see footnote 2 of Promoda).

2 Aakhra refer to places where Vaishnava mendicants or even pilgrims could stay at extremely nominal rates.

3 Srichandranath is a hill-based pilgrim spot for Hindu and Budhhist devotees (presently in Bangladesh) with a Shiva temple.

4 Refer to footnote 7 of the Introduction for thhana.

5 The word used in the Bangla original to describe the moonlight is kakjyotsna. The word is used to describe the kind of bright moonlight that gives the illusion of dawn and fools crows into cawing.

6 The dewan was the financial steward in a zamindar's/landowner's estate.

7 A naayeb was a rent collecting officer and administrator in a landlord's estate.

1 Kayastha is a caste category. Refer to footnote 23 of the Introduction for more details.

2 A caste category of a 'clean' shudra. Refer to footnote 23 of the Introduction.

3 The Bangla and Sanskrit word kula refers to a generic collectivity. The term was used more specifically in combination with the names of specific men to refer to units which would be designated as "clans", "lineages" or "families" in English. Ghosh-kula, for instance, would refer to the clan of persons who had a particular Ghosh as their "first ancestral male." Kulatyag (abandoning one's kula) was the word often used to refer to elopement. Even though it is clear that Premada and Hari had eloped together, the daroga at this point refers to the elopement

as a crime committed by Hari. He "forced Premada to abandon her kula". As discussed in footnote 4 of the Introduction, the insistence on referring to women's elopement as "being forced out of the kula" 1) helped rob women of their agency and framed their action as passive subjection and 2) helped punish the male partner for having "enticed" and "abducted" her.

4 For criminalizing of abortion see Introduction and footnote 3 of the Introduction.

5 Salaami refers to a gift of money.

1 Land gifted to a Brahmin was called brahmatra. The owners did not have to pay a tax for the gifted land.

1 I have translated the word "kalkut" as poisonous deceit. While that is one way of translating it, in Hindu Purana mythology, kalkut also refers to the deadly poison that was produced by the churning of the ocean by the deva and asura (roughly translated as gods and demons). The cultural reference embedded in the word is, unfortunately, lost in translation.

1 The inner quarters of upper caste/class households where the women of the family resided were out of bounds for outsiders. About antahpurs (women's quarters) in wealthy households in late 19th-century Bengal, Chitra Deb writes,

Everywhere, as far as women were concerned, there was overwhelming emphasis on aabroo (seclusion though the word also means honour), purdah (the veil), closed windows and doors. Women in their own houses, were prohibited from stepping on to the courtyards, going to terraces and there was of course never any question of their crossing the threshold on foot. 
2 Sheendhh kaata refers to a particular kind of burglary which involves digging a tunnel in order to break into the house.

3 Chandannagar, a town in Bengal, was also known as Farashdanga since it had been a French colony. Farash is the Bengali/Bangla word for French.

4 In all probability refers to Kamini planning to trick/force her sister (Sundari) into a life of prostitution in the city.

5 Within the caste patriarchal system, a widow's sexual life was relentlessly policed by extremely rigid and austere codes of enforced celibacy, bodily mortification and food restrictions. Their marginalization and exclusion from normal familial existence and sexual life often also resulted in being sent off to social oblivion (and not infrequently, indigence) in places of pilgrimage like Varanasi/ Kashi, Vrindavan and Nabadwip. Despite the possibilities of social change opened up by the Widow Remarriage Act (1861), the formalization of usufructuary rights of widows over their husbands' property, and also the radical marriage regulation of 1872, it was celibate widowhood that was apotheosized in the late nineteenth century context. In this case, even though the babu's daughter lived with her family, once her secret liaison becomes known to her father, she is exiled to Kashi.

1 The seventh day of the Durga Puja festivities. Panchami, shashthi, ashtami and navami are respectively the fifth, sixth, eighth and ninth days.

2 Dom refers to a so-called 'unclean' caste group found in large numbers in districts in the western fringe of Bengal. Traditionally, Doms were basket-makers, cultivators, labourers, musicians and midwives. Some were also scavengers. Refer to footnote 23 of the Introduction.

3 Sindoor refers to the vermilion mark on the forehead of Hindu women and is meant to be an identifiable mark of her being married.

1 The Kaivartyas, a scheduled caste, belonging to the regions of Assam, Bengal and Odisha, were traditionally engaged in the occupation of fishing.

2 In the epic Mahabharata, Virat was the king of Matsya and a cow baron, in whose court the Pandavas spent a year in concealment during their exile.

3 Panchayat refers to the village council or a governing body usually formed of influential old men of the village.

4 Mitin is a term of endearment for a dearly loved friend and is often used by a man for a female friend. It is clear from the account that the maid Girija gives to the daroga that both she and her employer's daughter (also Girija) think of the other as Mitin. There is also a tantalizingly vague hint at same-sex love between the two Girijas in her account which remains unexplored and attenuated.

5 Ghat refers to the banks of a river.

6 Gamchha refers to a piece of cloth used as a towel.

1 A dao would be similar to a machete.

2 Boishnobi/Vaishnavi refers to female practitioners of Vaishnavism in Bengal which is indelibly connected to the figure of Chaitanya-a devotee, mystic and teacher who lived from 1486 to 1533. Vaishnavism has a long and complex history both outside and in Bengal. Associated with the worship of Radha and Krishna, in Bengal it has also been significant for enabling the social mobility of non-Brahmin trading groups. In the nineteenth century it was hugely popular amongst many prominent Hindu houses as well as among so-called 'lower' classes and castes. According to Baptist missionary William Ward, at least onethird of the population of Bengal professed some form of Vaishnavism in 1815. For many Vaishnava women and men, renunciation was used as an option to leave normative caste, class, and gender roles and lead a wandering life. Boishnobi women were often literate and were even hired as teachers in elite 
households (like the Jorasanko Tagores) for educating the female members. From the nineteenth century, sexuality emerged (amongst certain sections of the bhadralok) as the key feature of disdain for the Vaishnavas. Terms such as "bawdy," "obscene," and "sexually explicit" were used to describe Vaishnava lyrics of the padabali kirtan. Similarly, the terms "prostitute" and "lax morals or virtues" were deployed as adjectives for Boishnobis/Vaishnavi who did not clearly belong to conservative and wealthy Vaishnava families and led unconventional lives.

1 Ghat refers to the landing-stage on the bank of a river/pond. Keoratala is a place in Kolkata where the ghat is used as a crematory.

2 Both Suvarna Banik and Goyala refer to caste groups in Bengal. While Suvarna Banik is associated with the mercantile group with dealings in gold and silver, Goyala is a caste group associated with pastoral activities. Refer to footnote 23 of the Introduction.

1 Cuttack is a town in Odisha, a neighbouring state to Bengal. Puri, another town in Odisha, is known for the famous Jagannath temple that draws several pilgrims from all over India. Oriya is a word used to refer to the inhabitants of Odisha.

2 The bagdis are a "scheduled caste" today. Variously described as "indigenous", "aboriginal" and "tribal", they are wood-cutters, fishermen, litter carriers, and agricultural wage labourers/share-croppers. Three sub-castes-Tentule, Kushmete and Mal-form this caste group. I am deeply indebted to Saswati Sengupta for the detailed information and history of caste groups in Bengal.

3 Panda refers to a network of men who operate within Puri and convince devotees visiting the Jagannath temple that they will be given a faster and smoother entry into the temple sanctum in exchange for money.

4 Often women from respectable and elite families travelled in groups (that were not necessarily segregated in terms of caste) to visit places of pilgrimage like Puri.

\section{Bibliography}

Basu, Swapan. (ed.) (2003) Sambad-Samayikpatre Unish Shataker Bangali Samaj (Nineteenth Century Bengali Society in Newspapers and Periodicals), Kolkata: Pashchimbanga Bangla Academy.

Biswas. A. and Acharya, A. (2013) Bangalir Battala, Kolkata: Anushtup.

Chatterjee, Bankim. (1872) Judicial File, Letter no. 149/27 and no. 13:252:335. (Letter from Baboo Bankim Chatterjee, Deputy Magistrate to the Deputy Magistrate of Murshidabad, West Bengal Archives).

Chattopadhyay, Basudeb. (2000) Crime and Control in Early Colonial Bengal, 1770-1860, Kolkata: K.P. Bagchi \& Co.

Chattopadhyay, Ramakhhoy. (1892) Pulish o Lokrakhhaa (Police and the Protection of People), Kolkata: Nobin Chandra Pal Publishers.

Dasgupta, Arindam. (ed.) (1958) Phire Daikha (Looking Back), The Memoirs of Priyanath Mukhopadhyay and Girish Chandra Basu, Kolkata: Subarnarekha Publications.

Dasgupta, S. and Pal, P. (ed.) (2013) Bakaullah r Daftar, Kolkata: Charchapada. De, Pachkari. (1905) Govindram, Kolkata: Bengal Medical Library. 
Ghosh, Baridbaran. (ed.) (2011) Pachkari De Rachnabali, vol. 1. Kolkata: Karuna Prakashani.

Ginzburg, Carlo. (1990). Ecstasies: Deciphering the Witches' Sabbath, London: Hutchindon Radius.

Joshi, Priya. (1995) In Another Country: Colonialism, Culture, and the English Novel in India, New York: Columbia University Press.

Knight, Stephen. (2015) “The Postcolonial Crime Novel” in Ato Quayson (ed.) The Cambridge Companion to the Postcolonial Novel, Cambridge: Cambridge University Press, pp. 166-187.

Metcalfe, C.T. (1982) “Annual Administrative Report, April 30, 1878” in Tapan Chattopadhyay (ed.) The Story of Lalbazar: Its Origin and Growth, Kolkata: Firma KLM Pvt. Ltd.

Mukhopadhyay, Arun. (ed.) (2004) Mukhopadhyay, Priyanath. (1892-1903) Darogar Daftar, Vols. I and II, Kolkata: Punashcha.

Nandi, Baninath. (1898) "Prakashaker Mantabya (Publisher's Comments)" in Darogar Daftar, year 7, no. 73, Kolkata: Sikdarbagan Bandhab Pustakalay.

Robb, Peter. (1991) “The Ordering of Rural India” in David M. Anderson and David Killingray (eds) Policing the Empire: Government, Authority and Control, 1830-1940, Manchester: Manchester University Press, pp. 126-150.

Rowland, Susan. (2001) From Agatha Christie to Ruth Rendell: British Women Writers in Detective and Crime Fiction, Basingstoke, UK: Palgrave Macmillan.

Roy, S. and Sengupta, S. (2019) “'haan haan mein alaida hoon!' (Yes, Yes, I am Different!): The Disorderly Bibi in Sabib, Bibi aur Ghulam (1962)" in S. Sengupta, S. Roy and S. Purkayastha (eds.) 'Bad' Women of Bombay Films: Studies in Desire and Anxiety, Switzerland: Palgrave Macmillan.

Sarkar, Tanika. (2001/2013) Hindu Wife, Hindu Nation: Community, Religion and Cultural Nationalism, Delhi: Permanent Black.

Sen, Sukumar. (1988) Crime Kahini r Kaal Kranti (The Changes in the Crime Novel), Kolkata: Ananda Publishers.

Spivak, Gayatri, C. (2012) “The Politics of Translation" in Lawrence Venuti (ed.)

The Translation Studies Reader, London \& New York: Routledge.

Tagore, Rabindranath. (2001) Galpaguchha, Vol. II, Kolkata: Viswabharati.

Venuti, L. (1998) The Scandals of Translation: Towards an Ethics of Difference, London \& New York: Routledge.

Basu, Swapan. (ed.) (2003) Sambad-Samayikpatre Unish Shataker Bangali Samaj (Nineteenth Century Bengali Society in Newspapers and Periodicals), Kolkata: Pashchimbanga Bangla Academy.

Biswas. A. and Acharya, A. (2013) Bangalir Battala, Kolkata: Anushtup.

Chatterjee, Bankim. (1872) Judicial File, Letter no. 149/27 and no. 13:252:335. (Letter from Baboo Bankim Chatterjee, Deputy Magistrate to the Deputy Magistrate of Murshidabad, West Bengal Archives).

Chattopadhyay, Basudeb. (2000) Crime and Control in Early Colonial Bengal, 1770-1860, Kolkata: K.P. Bagchi \& Co.

Chattopadhyay, Ramakhhoy. (1892) Pulish o Lokrakhhaa (Police and the Protection of People), Kolkata: Nobin Chandra Pal Publishers.

Dasgupta, Arindam. (ed.) (1958) Phire Daikha (Looking Back), The Memoirs of 
Priyanath Mukhopadhyay and Girish Chandra Basu, Kolkata: Subarnarekha Publications.

Dasgupta, S. and Pal, P. (ed.) (2013) Bakaullah r Daftar, Kolkata: Charchapada.

De, Pachkari. (1905) Govindram, Kolkata: Bengal Medical Library.

Ghosh, Baridbaran. (ed.) (2011) Pachkari De Rachnabali, vol. 1. Kolkata: Karuna Prakashani.

Ginzburg, Carlo. (1990). Ecstasies: Deciphering the Witches' Sabbath, London: Hutchindon Radius.

Joshi, Priya. (1995) In Another Country: Colonialism, Culture, and the English Novel in India, New York: Columbia University Press.

Knight, Stephen. (2015) “The Postcolonial Crime Novel” in Ato Quayson (ed.) The Cambridge Companion to the Postcolonial Novel, Cambridge: Cambridge University Press, pp. 166-187.

Metcalfe, C.T. (1982) “Annual Administrative Report, April 30, 1878” in Tapan Chattopadhyay (ed.) The Story of Lalbazar: Its Origin and Growth, Kolkata: Firma KLM Pvt. Ltd.

Mukhopadhyay, Arun. (ed.) (2004) Mukhopadhyay, Priyanath. (1892-1903) Darogar Daftar, Vols. I and II, Kolkata: Punashcha.

Nandi, Baninath. (1898) "Prakashaker Mantabya (Publisher's Comments)" in Darogar Daftar, year 7, no. 73, Kolkata: Sikdarbagan Bandhab Pustakalay.

Robb, Peter. (1991) “The Ordering of Rural India” in David M. Anderson and David Killingray (eds) Policing the Empire: Government, Authority and Control, 1830-1940, Manchester: Manchester University Press, pp. 126-150.

Rowland, Susan. (2001) From Agatha Christie to Ruth Rendell: British Women Writers in Detective and Crime Fiction, Basingstoke, UK: Palgrave Macmillan.

Roy, S. and Sengupta, S. (2019) “'haan haan mein alaida hoon!' (Yes, Yes, I am Different!): The Disorderly Bibi in Sabib, Bibi aur Ghulam (1962)" in S. Sengupta, S. Roy and S. Purkayastha (eds.) 'Bad' Women of Bombay Films: Studies in Desire and Anxiety, Switzerland: Palgrave Macmillan.

Sarkar, Tanika. (2001/2013) Hindu Wife, Hindu Nation: Community, Religion and Cultural Nationalism, Delhi: Permanent Black.

Sen, Sukumar. (1988) Crime Kahini r Kaal Kranti (The Changes in the Crime Novel), Kolkata: Ananda Publishers.

Spivak, Gayatri, C. (2012) “The Politics of Translation” in Lawrence Venuti (ed.) The Translation Studies Reader, London \& New York: Routledge.

Tagore, Rabindranath. (2001) Galpaguchha, Vol. II, Kolkata: Viswabharati. Venuti, L. (1998) The Scandals of Translation: Towards an Ethics of Difference, London \& New York: Routledge. 